\title{
Global Eradication of Money Laundering and Immunity for Legal Practitioners under the Nigerian Money Laundering Regulation: Lessons from the United Kingdom
}

\author{
Felix Emeakpore Eboibi ${ }^{\odot}$, Inetimi Mac-Barango \\ Faculty of Law, Niger Delta University, Wilberforce Island, Yenagoa, Bayelsa State, Nigeria \\ Email: felixeboibi@mail.ndu.edu.ng, inetimi.zuofa@gmail.com
}

How to cite this paper: Eboibi, F. E., \& Mac-Barango, I. (2019). Global Eradication of Money Laundering and Immunity for Legal Practitioners under the Nigerian Money Laundering Regulation: Lessons from the United Kingdom. Beijing Law Review, 10, 769-794.

https://doi.org/10.4236/blr.2019.104042

Received: May 25, 2019

Accepted: August 16, 2019

Published: August 19, 2019

Copyright $\odot 2019$ by author(s) and Scientific Research Publishing Inc. This work is licensed under the Creative Commons Attribution International License (CC BY 4.0).

http://creativecommons.org/licenses/by/4.0/

c) (i) Open Access

\begin{abstract}
Legal professionals are generally depicted as possible "gatekeepers" to money laundering as a result of the kind of services they render to clients by the Financial Action Task Force (FATF). Consequently, there is the global quest for anti-money laundering obligations to be imposed on legal professionals. However, recent legal development in Nigeria seems to have absolved legal practitioners from anti-money laundering regulations based on the Nigerian Court of Appeal judgment between the Central Bank of Nigeria $v$ Registered Trustees of Nigerian Bar Association \& Attorney General of the Federation. This paper critically examines how this development impinges on the fight against money laundering and its implication on legal professionals and the Nigerian polity. Comparatively, the United Kingdom is globally seen as one of the countries that have complied with the FATF Recommendations with specific reference to legal professionals. In this regard, the United Kingdom's approach is suggested for adaptation by the Nigerian government and Nigerian Bar Association.
\end{abstract}

\section{Keywords}

Nigerian Money Laundering Regulation, Financial Action Task Force, Legal Professionals, United Kingdom Money Laundering Regulation

\section{Introduction}

Globally, money laundering denotes a procedure whereby the earnings of crime, and the exact ownership of the said earnings, are transformed and integrated into the society to ensure that the earnings seem to have come from a legal 
source. ${ }^{1}$ It is "the process of making illegally-gained proceeds (i.e. "dirty money") appear legal (i.e. "clean money") ${ }^{2}$ (Yantis et al., 2018). It presupposes "any act that obscures the illicit nature or the existence, location or application of proceeds of crime" (Schlenter, 2013; De Koker, 2007). Money Laundering involves three processes: placement; layering; and integration. ${ }^{3}$ For the purposes of this research, legal professionals mean "a firm or a sole practitioner who by way of business provides legal or notarial services to other persons. It does not include legal professionals employed by a public authority or working in-house."4 Considering the nature of legal services independent legal professionals ${ }^{5}$ render to their clients, there is the possibility of them being used to further money laundering purposes. Since legal professionals deal with clients' money, they can be used to introduce the earnings from crime into the financial system, especially when banks and financial institutions have developed anti-money laundering processes to avoid being detected (placement). Once this is successfully done, an independent legal professional may be used to prevent or conceal the detection of the source of the earnings of crime by plowing same into complex transactions like trusts and companies in several jurisdictions (layering). Thereafter, the earnings would seem legal and be subsequently used by the legal professional for investment purposes such as the purchase of properties and settlement of litigation expenses, amongst others (integration). ${ }^{6}$ Unless, money laundering is successfully combatted, it constitutes a grave threat to the global society. It accounts for accrued loss to revenue and endanger lives while also breeding and engineering the commission of other heinous criminal activities. ${ }^{7}$

Based on the foregoing and in order to combat the involvement of legal professionals in money laundering activities globally, the Financial Action Task Force (FATF) being an inter-governmental organization decided to put in place national and international policies and saw the extension of the application of the $40+9$ recommendations to lawyers. Precisely, in 2001, the FATF identified legal professionals as possible "gatekeepers" to money laundering and terrorist financing activities based on the kind of services they render to clients. ${ }^{8}$ Consequently, in 2008 the FATF issued guidelines for lawyers to apply the risk-based ${ }^{1}$ Legal Sector Affinity Group (2018) Anti-Money Laundering, Guidance for the Legal Sector, p.12. ${ }^{2}$ History of Anti-Money Laundering Laws, U.S DEPT OF THE TREASURY, FIN. CRIMES

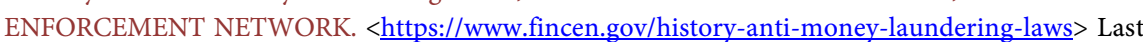
accessed 11 June 2019.

${ }^{3} I d$.

${ }^{4}$ Regulation 8 of the Money Laundering Terrorist Financing and Transfer of Funds (Information on the Payer) Regulations 2017.

${ }^{5}$ Independent legal professional, legal professionals, legal practitioners \& lawyers shall be used interchangeably in this paper to mean the same thing. Regulation 8 of the Money Laundering Terrorist Financing and Transfer of Funds (Information on the Payer) Regulations 2017 defines independent legal professional as "a firm or a sole practitioner who by way of business provides legal or notarial services to other persons. It does not include legal professionals employed by a public authority or working in-house." Independent legal professionals are interchangeably used in this work as legal professionals, lawyers and legal practitioners.

${ }^{6}$ Legal Sector Affinity Group, supra, note 1.

${ }^{7}$ Id.

${ }^{8}$ FATF Report on Money Laundering Typologies 2000-2001. 
approach in respect to issues bordering on anti-money laundering. Part of the recommendation in the lawyer's Guidance is for lawyers to engage in due diligence prior to being engaged by a client and an examination of the origin of client funds. Moreover, Politically Exposed Persons (PEPs) and lawyers' services that involve the transfer of funds via accounts under their control and services that require lawyers to obscure illegitimate benefits or ownership from competent authorities should be treated as high risk $^{9}$ (Malish, 2017a). Although, the 2008 guidance did not mandate lawyers to be involved in the already existing FATF Recommendations that have to do with "suspicious transaction reports" (STRs) but in 2012 the FATF insisted through her recommendation that lawyers and other "designated non-financial businesses and professions" (DNFBPs) should mandatorily report transactions that are suspicious, same way financial institutions are required to do in course of dealing with financial transactions ${ }^{10}$ (Malish, 2017b).

What the FATF Recommendations have done is to put in place an international standard wholistic framework and measure which countries should ordinarily implement for the purpose of combatting money laundering and terrorist financing. The diversity of countries financial systems, administrative, legal and operational policies is taken cognizance of by the FATF Recommendations, hence, it notes that there cannot be identical policies in place to combat money laundering. In essence, countries are expected to implement the FATF Recommendations by adapting same to their peculiar situations to: "identify the risks, and develop policies and domestic coordination; pursue money laundering, terrorist financing and the financing of proliferation; apply preventive measures for the financial sector and other designated sectors; establish powers and responsibilities for the competent authorities (e.g., investigative, law enforcement and supervisory authorities) and other institutional measures; enhance the transparency and availability of beneficial ownership information of legal persons and arrangements; and facilitate international cooperation"11 (Malish, 2017a).

In the light of the above, numerous countries have adapted the FATF Recommendations and FATF Lawyers Guidance as part of their national anti-money laundering legal policy or regulation or have specifically enacted new sections of legal policy or regulation. Irrespective of this, many countries are caught with the desired or full implementation of the FATF Recommendations as it applies to lawyers generally (Malish, 2017b). This is arguably borne out of the fiduciary duties and restriction on privilege communication between legal professionals and their clients and how it could impede on reporting obligations in respect to money laundering. For example, the Unites States of America (American Bar Association (ABA)) and Nigeria (Nigerian Bar Association (NBA) $)^{12}$

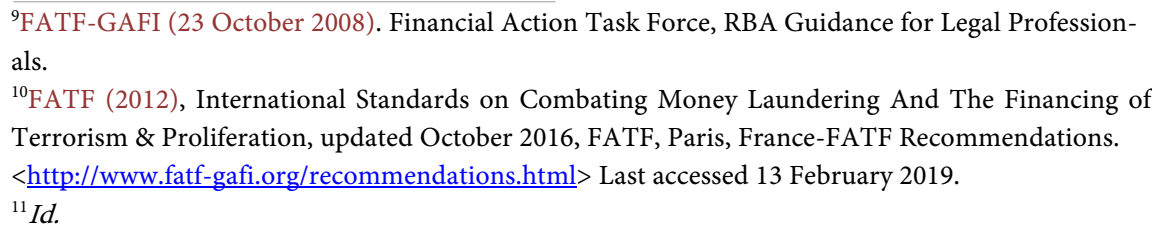


(Malish, 2017a; Rose 2009). The United Kingdom is globally seen as one of the countries that have complied with the FATF Recommendations with specific reference to Lawyers ${ }^{13}$ (Malish, 2017a; Rose 2009). The United Kindom government in order to combat money laundering in the legal profession decided to enact and implement a powerful legislative framework: the Money Laundering Regulations 2007 together with the Proceeds of Crime Act 2002 (POCA) and the Terrorism Act 2000, which have now been replaced by the Money Laundering, Terrorist Financing and Transfer of Funds (Information on the Payer) Regulations 2017 on 26 June 2017. The immense successes recorded thus far by the UK government in the fight against money laundering in the legal profession is arguably due to the harmonious relationship and understanding with the UK's Law Society and the Solicitors Regulation Authority (SRA), the UK's version of the Nigerian Bar Association (NBA) which regulates law firms and solicitors in England and Wales ${ }^{14}$ (Malish, 2017a; Rose 2009). The SRA believes in lawyers significant obligation towards the fight against money laundering in the UK. For instance, under outcome 7.5 of the SRA Code of Conduct, UK Solicitors are obliged to "comply with ... anti-money laundering ... legislation."

Comparatively, have the Nigerian government and the Nigerian Bar Association done enough to combat money laundering in the legal profession? Unlike, the United Kingdom, Nigeria had a poor anti-money laundering regime and was consquently blacklisted by the FATF and made part of Non-Cooperative Countries and Territories (NCCT) sometime in $2001 .{ }^{15}$ Considering, the disadvantageous nature of the impact on the Nigerian economy and image globally, the Nigerian government enacted the Money Laundering (Prohibition) Act (MLPA) 2004 and the Economic and Financial Crimes Commission (EFCC) (Establishment) Act 2004. ${ }^{16}$ Both laws gave birth to the EFCC, the Nigerian Financial Intelligence Unit (NFIU) and the Special Control Unit against Money Laundering (SCUML) for the purpose of enforcing the MLPA through the investigation and combatting of financial and economic crimes. ${ }^{17}$ SCUML was a departmental creation under the Federal Ministry of Industry, Trade \& Investment (Formerly known as the Federal Ministry of Commerce \& Industry) and empowered to handle the supervision, monitoring and regulation of the activites of Designated Non-Financial Institutions (DFNIs (now re-designated by FATF and the CBN as "Designated Non-Financial Businesses and Professions-DNFBPs")) and acquaint the EFCC. ${ }^{18}$ On the otherhand, the NFIU engages in "recept, analysis and dissemination of financial intelligence to law enforcememnt agencies." ${ }^{19}$ The MPLA




was repealed by the Money Laundering (Prohibition) Act 2011 and subsequently amended by the Money Laundering (Prohibition) (Amendment) Act 2012 due to certain observed lapses and to fully adapt to the FATF Recommendations in respect to financial institutions customer due diligence and DFNIs which included legal practitioners as one. Eventually, sometime in 2006, the FATF delisted Nigeria from her blacklist and held Nigeria to have complied with her requirements in $2013 .^{20}$

It must be noted that these regulations were never enforced or implemented against legal pracitioners in Nigeria arguably because the Nigerian Bar Association sought to negotaite with the Nigerian government and its agencies to allow NBA regulate the activities of Nigerian Legal Practitioners in respect to money laundering as against SCUML (Ogundipe, 2015). Unfortunately, the Central Bank of Nigeria via a circular dated 2 August 2012 issued a directive mandating all banks and financial institutions to request for registration evidence of all DFNIs inclusive of legal practitioners with SCUML prior to creating a new business relationship with them while old customers were asked to update their records within six months from the date of publication of the circular (Ogundipe, 2015; Inko-Tariah, 2016). ${ }^{21}$ When all attempts to find a resolution with SCUML could not yield any positive outcome by the NBA, as the umbrella body of all legal practitioners in Nigeria, it resolved to institute an action against the Nigerian government and the CBN at the Federal High Court. In a considered judgment delivered on 17 December 2014, the Federal High Court held in Suit No. FHC/ABJ/CS/173/2013 Registered Trustees of Nigerian Bar Association v. Attorney General of the Federation \& Central Bank of Nigeria that the MLPA 2011 DFNI provisions that the SCUML and CBN sought to enforce against legal practitioners were invalid and consequently struck down, as long as they were done in a bid to regulate legal practitioners (Ogundipe, 2015; Inko-Tariah, 2016). ${ }^{22}$ Dissatified with the judgment, the CBN appealed before the Court of Appeal, which subsequently affirmed the decision of the Federal High Court. ${ }^{23}$ Based on the Court of Appeal's Judgment, can it be categorically said that Nigerian Legal Practitioners are immuned from statutory anti-money laundering regulations contrary to the FATF Recommendations? Is there any lesson to be

\footnotetext{
${ }^{18}$ By virtue of s.25 MLPA 2011 DNFIs mean dealers in jewellery, cars and luxury goods, chartered accountants, audit firms, tax consultants, clearing and settlement companies, legal practitioners, hotels, casinos, supermarkets or other such businesses as the Federal Ministry of Commerce or appropriate regulatory authority may from time to time designate.

${ }^{19}$ EFCC Act, supra, note 17.

${ }^{20}$ FATF Recommendation 26 of 2012. The establishment of money laundering regulation and enforcement agencies resulted to the delisting of Nigeria from the blacklist of FATF.

http://www.efccnigeria.org/. Last accessed 1 February 2019.

${ }^{21}$ Central Bank of Nigeria Circular (2012)

<http://cenbank.org/Out/2012/circulars/fpr/Additional\%20KYC\%20Requirement.pdf> Last accessed 11 February 2019.

${ }^{22}$ Registered Trustees of Nigerian Bar Association v. Attorney General of the Federation \& Central Bank of Nigeria Suit No. FHC/ABJ/CS/173/2013 (Unreported) Judgment delivered by the Federal High Court, Abuja on 17 December 2014, per Justice Gabriel Kolawole.
} 
drawn from the UK's approach in combatting money laundering in respect to legal practitioners?

The imperitiveness of unravelling these questions posed cannot be overemphasized, considering the recent corruption and money laundering charges preferred against the President of the Nigerian Bar Association, (Paul Usoro SAN) and other senior legal practioners currently under the investigation of the EFCC. These are issues that relates to the management of clients' accounts and monies for legal services rendered and their relationship with legal practitioners obligation to the fight against money laundering. An examination of the Court of Appeal judgment would show whether or not Nigerian legal practioners are now free to allow criminals to launder money through clients account and or accept monies in disguise of legal services not rendered to promote money laundering.

This paper examines money laundering from the perpective of the legal profession. It explains the relationship between legal professionals and money laundering and how legal professionals can be used to launder money globally. It identifies the role of FATF towards the establishment of international standard in an attempt to combat money laundering globally as it specifically relates to legal professionals. It notes that the FATF measures are ordinarily expected to be adapted by countries globally through their domestic anti-money laundering regulations or legal frameworks. It questions the veracity or otherwise of the implementation of the FATF Recommendations in Nigeria in respect to legal practitioners. It examines the Nigerian anti-money laundering regulations and its impact on legal practitioners and the Nigerian polity. It thereafter determines whether or not the Nigerian Court of Appeal judgement between the $C B N \mathrm{~V}$ Registered Trustees of Nigerian Bar Association \& AG Federation actually grants immunity to legal practitioners from the Nigerian money laundering regulations. In the same vein, the implication of the absence of anti-money laundering measures on legal practitioners is explored. Thereafter, from a comprative perspcetive, the UK's approach to money laundering regulation of legal professionals is highlighted and shown to be national example to countries who are politically willing to fight the scourge of money laundering from the perpspective of legal practitioners. It consequently, recommends to the Nigerian government and the NBA to adapt the processes and procedures currently being applied in the UK in respect to the fight against money laundering by legal practitoners and other positive steps that should be taken.

\section{Literature Review}

Reider-Gardan, et al. (2012), examines the enforcement of anti-money laundering regulations from a comparative perspective. They note that quite a number of lawyers have been criminally convicted of money laundering for conducting laundering activities through their firms in the year 2011. The United States, Singapore, the United Kingdom and Spain were given as examples and that the ${ }^{23}$ Central Bank of Nigeria v. NBA \& Attorney General of the Federation, Appeal No. CA/A/202/2015 (Unreported) Judgement delivered by the Court of Appeal, Abuja on 14 June 2017, per Abdu Aboki (JCA). 
recorded convictions attest to lawyers being gatekeepers and consequently subject to similar rules that are applicable to the financial industry. Although, the Nigerian MLPA 2011 is referred to but discussions about recent developments that resulted to the amendment of the MLPA 2011 and its consequent impact on legal practitioners are absent. Most importantly, the Nigerian Court of Appeal interpretation of the impact of the Nigerian Money Laundering Regulation on legal practitioners in $C B N{ }_{v}$ Registered Trustees of Nigerian Bar Association \& $A G$ Federation is not captured. Moreover, the UK's Law Society and Government's initiatives towards the prevention of lawyers from engaging in money laundering related offences, which has consequently made them the "gold standard" for anti-money laundering regulation in respect to legal professionals is also not captured. In a nutshell, Reider-Gardan, et al. (2012) is focused on pre-2011 and 2011 money laundering and lawyers' issues while this research work encapsulates recent developments, particularly from Nigeria and the UK.

Gaetke \& Welling (1992), on their own, discusses the enactment of money laundering laws in the US to negate the use of proceeds from crime. They argue that since such monies can be used to settle legal professional fees, money laundering laws enacted have impact on lawyers directly. Consequently, an analysis of how money laundering laws collectively impinge on criminal defense lawyers was undertaken. They started by taking a holistic look at how the federal money laundering laws impact criminal defense lawyers upon receipt of legal fees for their work. However, this research work takes a critical look at whether or not legal practitioners are bound by the Nigerian Anti-Money Laundering Regulation in spite of the already existing Legal Practitioners Act (LPA), the Rules of Professional Conduct for Legal Practitioners, 2007 and Section 192 of the Evidence Act 2011, which seem to have covered the field in respect to the regulation of the activities of Nigerian legal practitioners and specifically deals with law practice.

Again, Terry, (2014), addresses the efforts of the FATF in fighting against money laundering and notes that money laundering is a federal crime in the US which lawyers are subject to. How the US legal profession went about educating lawyers on the avoidance of involvement in money laundering is articulated. This current research work, from a different perspective, gives a detail overview of how FATF has impacted the quest to rid nations of money laundering and how this gesture resulted to Nigeria's enactment of her Money Laundering Regulation. Although, Terry's work is based on the US lawyers relationship with money laundering, it does not comparatively determine Nigeria's challenges arising from her money laundering regulation in respect to lawyers and the effect of the CA judgment in $C B N{ }_{v}$ Registered Trustees of Nigerian Bar Association \& $A G$ Federation on lawyers.

In another development, Ogundipe (2015), Eze (2013), Lawyard (2017) and Inko-Tariah (2016) highlights the historical antecedent of the Nigerian anti-money laundering regulation and its relationship with legal practitioners; the role of the EFCC, NFIU, CBN and SCUML in the enforcement of the an- 
ti-money laundering regulation and the NBA's resistance to be bound by the CBN's directive in that respect. They respectively captured and analyzed the Federal High Court judgment delivered on 17 December 2014 by Justice Gabriel Kolawole, in Suit No. FHC/ABJ/CS/173/2013-Registered Trustees of Nigerian Bar Association v. Attorney General of the Federation \& Central Bank of Nigeria to the effect that the MLPA 2011 DFNI provisions that the SCUML and CBN sought to enforce against legal practitioners were invalid and consequently struck down, as long as they were done in a bid to regulate legal practitioners. Nevertheless, the aftermath of the Federal High Court's judgment and the position taken by the Nigerian Court of Appeal in CBN v Registered Trustees of Nigerian Bar Association \& AG Federation is not captured, which has consequently been critically adumbrated in this research work.

In addition, the aforementioned literatures did not do a comparative analysis between the Nigerian anti-money laundering regulation and her UK counterpart from the perspective of legal practitioners as it concerns the potential conflict between lawyers' duty to his or her clients' and the duty to report suspected money laundering activities. This research work articulates these and for an effective and efficient fight against money laundering in Nigeria, the UK's anti-money laundering regime with respect to legal professionals is recommended for adaptation by the Nigerian government and NBA haven resolved the challenges posed by lawyers' duty to his or her clients' and the duty to report suspected money laundering activities in the UK. The corollary is that this research work serves as a gap filling of the challenges posed by the Nigerian anti-money laundering regime and its impact on legal practitioners.

\section{The Impact of the Nigerian Money Laundering Regulation on Legal Practitioners}

The Money Laundering Act 1995 was the first Nigerian anti-money laundering legislation but was basically related to the proceeds of narcotics trade (Ogundipe, 2015). It was however replaced with the MLPA 2003 with copious adoption of the hitherto FATF Recommendations of 1996 and subsequently repealed in no distance time by the MLPA 2004 (Ogundipe, 2015). Legal practitioners were for the first time made part of the definition of DFNIs under the MLPA 2004 and were mandated in addition to abstain from practices that would involve them in the laundering of proceeds of crime, under the MLPA 2003, to keep details of cash transactions that were in excess of the naira equivalent of US\$5000 and send same to the Federal Ministry of Commerce (now EFCC in MLPA 2011) (Ogundipe, 2015). SCUML was established to enforce this section of the legislation as noted earlier in this work.

Pursuant to SCUML's mandate, it pressed on the implementation of the aspect of the law on DFNIs by pressing on the National Advisory Council against Money Laundering (Eze, 2013). Consequently, recognizing the obvious loopholes in the Nigerian anti-money laundering legislation contrary to the FATF 
Recommendations and the quest for a better anti-money laundering regime, sometime in February 2010 the Nigerian government politically made a commitment to the Inter-Governmental Action Group against Money Laundering in West Africa (GIABA) and FATF to address the deficiencies and loopholes so that Nigeria can be exited from the list of countries termed to constitute high risk to the financial system globally (Eze, 2013). In this regard, the Presidential Committee on FATF was put in place to ensure that the MPLA 2011 is enacted and amended (Eze, 2013). The MLPA 2011 was eventually enacted by the Nigerian government in line with most of the FATF Recommendations (Eze, 2013). For instance, on predicate offences for money laundering, which generated a lot of controversies in the celebrated case of Federal Republic of Nigeria v. James Ibori \& 5 others (Charge No.: FHC/ASB/IC/09) in respect to the interpretaion of section 14 of the MLPA 2004 to be limited to funds derived from crimes traceable to narcotic drugs and psychotropic substances, has now been amended by section 15 of the MLPA 2011. ${ }^{24}$ The said limitation has been removed and a broad list of predicate offences in accordance with the FATF Recommendations for money laundering has been inserted, extending it beyond funds acquired from drug related offences.

Sections 5 and 25 of the MLPA 2011 relates to legal practitioners keeping of record and active reporting amongst others of cash transactions handled for their clients. The essence is to locate the movement, volume and source of the money with the aim of detecting or preventing the funding of predicate offences and other illegal activities known or unknown to the legal practitioner. It mandates legal practtitioners to report transactions that are in excess of US\$1000 to SCUML, empowered with the duty of enforcing the statutory responsibility of the Federal Ministry of Trade and Industry as a specialized unit under it pursuant to the Federal Executive Council of Nigeria (Decision No. EC 2005) 2861 in September 2005. It also requires the EFCC "to demand and receive reports directly from" legal practitioners and should they refuse to comply, criminal sanctions may ensue. These may be in the form of N250,000 (US\$694) fine daily for the period of non-compliance and other penalties such as not less than two years and not more than three years terms of imprisonment for individuals. ${ }^{25}$

Section 7 of the MLPA 2011 mandates legal practtioners to preserve record of their clients identification for a period of at least five years in addition to all transaction records and any suspicious transaction report. Section 8 makes it mandatory upon demand for all the records mentioned above to be sent to the CBN or National Drug Law Enforcement Agency (NDLEA) and any other regulatory authority as may be determined by EFCC, by order published in the gazette, specify. Section 9 empowers the CBN to impose a penalty of not less than N1,000,000 (US\$2778) or suspension of any license issued to a legal practi-

${ }^{24}$ Federal Republic of Nigeria v. James Ibori \& 5 others, Charge No.: FHC/ASB/IC/09, (unreported); Commercial Law Development Services, Exclusive Interview with Ogwemoh Sylva on Legal Practitioners and Money Laundering, (July 2018) Vol. 1 Issue 2, Commercial Law Newsletter, 2-6.

${ }^{25}$ MLPA 2011, ss.5 \& 25. 
tioner for failure to develop programmes in a bid to combat the laundering of the proceeds of crime, through: a) putting in place compliance officers at management level both at the head office and branches; b) Ensuring the organization of training programmes from to time to time for the benefit of employees; c) Information collected should be centralized; and d) An internal audit unit should be created to ensure compliance and effectiveness of measures put in place to enforce provisions of the Act. Section 10 makes it mandatory for individual legal practitioners that are involved in transaction in excess of N5million (US\$13,889) or N10million (US\$27,778) or its equivalent in the case of a corporate legal firm to report to EFCC within 7 and 30 days respectively. Failure to report is an offence and the legal practitioner is laible on conviction to not less than $\mathrm{N} 250,000$ (US\$694) and not more than N1million (US\$2778) for each day the contravention continues. ${ }^{26}$

Morover, to ensure a stronger anti-money laundering regime in Nigeria and a fulfilment of the requirements of the FATF Recommendations, arguably, FATF, GIABA, EFCC and CBN mounted pressure on the Nigerian National Assembly to amend the MLPA 2011 through an enactment of the Money Laundering (Prohibition) (Amendment) Act (MLPAA) 2012, which is currently operative in Nigeria. Section 3 of the MLPA 2011 was amended by Section 3 of the MLPAA 2012. By virtue of the said amendement, legal practitioners are now compulsorily mandated to: "a) identify a customer, whether permanent or occasional, natural or legal person, or any other form of legal arrangements, using identification documents such as international passport, driving license, national identity card or any other form of identification prescribed in any relevant regulation; b) verify the identity of the customer using reliable, independent source documents, data or information; and c) identify the beneficial owner and take reasonable measures to identity the beneficial owner using reliable information to the satisfaction of the legal practitioner." ${ }^{\text {27 }}$ Section 3 (2) introduces Customer Due Diligence (CDD) meaures for legal practitioners to undertake, when: a) establishing business relationships; b) carrying out occasional transactions above the applicable designated threshold..; c) carrying out occasional transaction that are wire transfers; d) there is a suspicion of money laundering or terrorist financing e) legal practitioners have doubts about the veracity or adequacy of customer data identification previously obtained. ${ }^{28}$ These gives the legal practitioner an extra burden to critically examine every transaction engaged in pertaining to any busness relationship by ensuring that infomation within his knowledge about his client, client's business and risk profile is consistent. Mandatorily, legal practitioners must now put mechanisms in place for the purpose of mitigating any perceived risk in course of dealing with clients (Eze, 2013).

Section 15 of the MLPA 2011 is amended by Section 9 MLPAA 2012, hence a new Section 15 is introduced as follows:

\footnotetext{
${ }^{26}$ MLPA 2011, s.9.

${ }^{27}$ MLPAA 2012, s.3(1).

${ }^{28} I d$., s.3(2).
} 
“15 1) Money Laundering is prohibited in Nigeria.

2) Any person or body corporate, in or outside Nigeria, who directly or indirectly a) conceals or disguises the origin of; b) converts or transfers; c) removes from the jurisdiction; or d) acquires, uses, retains or takes possession or control of; any fund or property, knowingly or reasonably ought to have known that such fund or property is, or forms part of the proceeds of an unlawful act; commits an offence of money laundering under this Act.

3) A person who contravenes the provisions of subsection (2) of this section is liable on conviction to a term of not less than seven years but not more than 14 years imprisonment.

4) A body corporate who contravenes the provisions of subsection (2) of this section is liable on conviction to (a) a fine of not less than 100 per cent of the funds and properties acquired as a result of the offence committed; and (b) withdrawal of license.”

The corollary is that a legal practitioner practicing individually who contavenes the aforementioned provision would be liable to between 7 and 14 years terms of imprisonment or 100 percent of funds or properties acquired, in addition to withdrawal of license if he operates as a corporate body. ${ }^{29}$

In another development, pursuant to Section 5 (4) MLPA 2011 (as amended) which mandates the Honourable Minister of Commerce and Industry to make regulations for the Designated Non-Financial Businesses and Professions (DNFBPs) for the purpose of protecting the designated sectors from money laundering and combatting the financing of terrorism, the Special Control Unit Against Money Laundering Anti-Money Laundering/Combating the Financing of Terrorism (AML/CFT) Regulations for Designated Non-Financial Businesses and Professions in Nigeria 2013 was established. The Regulation is steered by the Money laundering Prohibition Act 2011 (as amended), Terrorism Prevention Act 2011 (as amended), Financial Action Task Force 40 recommendations (February 2012) as well as international best practices documents. The essence of the Regulation is to guide DNFBP's towards the implementation of the Know Your Customer (KYC) and Customer Due Diligence (CDD) requirements for the DNFBP sector.

Apart from the Regulation's inclusion of legal practitioners as DNFBPs, it also jointly defined "Legal practitioners, notaries public and accountants" to mean sole practitioners, partners or employed professionals within professional firms. It is not meant to refer to "internal" professionals that are employees of other types of businesses, nor to professionals working for government agencies, who are already subject to measures designed to combat money laundering." 30 The Regulation is a mere reiteration of the legal provisions hereinbefore examined specifically bordering on legal practitioners obligations to their clients in Sections 7, 8, 9, $10 \& 3,15$ of the MLPA(as amended).

Despite the above laudable anti-money laundering regulations against legal ${ }^{29} I d .$, s.15(4) \& (5). 
practitioners, they were not being enforced by the Nigerian government and her agencies until 2 August 2012 when the CBN rolled out a circular mandating all banks and financial institutions to request for registration evidence of all DFNIs or DNFBPs inclusive of legal practitioners with SCUML prior to creating a new business relationship with them while old customers were asked to update their records within six months from the date of publication of the circular ${ }^{31}$ (Inko-Tariah, 2016). At the expiration of the six months period, the CBN issued a second circular dated 25 February 2013 extending compulsory compliance for another three months period and a further extension on 18 June 2013 to terminate on 31 December 2013.

Arguably, within this period the NBA sought an understanding and arrangement with the Nigerian government and her agencies to permit the lawyer's body to regulate themselves. The issues raised by the NBA revolves around the already existing legal frameworks: Legal Practitioners Act (LPA) 1976 (Cap. L11 Laws of the Federation (LFN) 2004); The Rules of Professional Conduct for Legal Practitioners (RPC) 2007; and the Evidence Act (EA) 2011 regulating legal practitioners generally; their conduct, remuneration and clients account prior to the enactment of the anti-money laundering regulations in respect to Nigerian Legal practitioners. Sections $1 \& 1$ (2) of the LPA made provision for the Bar Council and President of the NBA while the Body of Benchers is empowered by Sections 3, 4, 7 to engage in formal Call to Bar of individuals seeking to practice as legal practitioners having obtained Barrister at Law Certificate and who after the call must enroll his/her name on the Register of Roll for Legal practitioners in Nigeria before the Supreme Court of Nigeria. The Legal Practitioners Privileges Committee is by virtue of section 5 in charge of conferring the Senior Advocate of Nigeria (SAN) rank while the Legal Practitioners Disciplinary Committee is empowered by section 10 to handle cases of Lawyers professional misconduct. Section 11 establishes punishment for professional misconduct etc. The LPDC can order a legal practitioner's name to be struck off the roll; suspension from practice for a period of time, which may include an order to refund money paid or documents given or other punishment once the legal practitioner is proved or found guilty of infamous conduct or other misconduct. Hence, issues relating to Legal Practitioners remuneration and clients' accounts are covered by the LPA. Specifically, sections 20 and 21 already established the regulation of financial transactions between lawyers and their clients. Moreover, Rules 7, 14, 19, 55 of the RPC which came into force on 2 February 2007 imposed on Lawyers certain duties and obligations and in default, provides punishment for any Legal Practitioner that is in breach based on the LPA. Also section 192 of the EA imposed an obligation on Legal Practitioners not to disclose any communication

\footnotetext{
${ }^{30}$ Special Control Unit against Money Laundering Anti-Money Laundering/Combating the Financing of Terrorism (AML/CFT) Regulations for Designated Non-Financial Businesses and Professions in Nigeria 2013.

${ }^{31}$ Id; Central Bank of Nigeria Circular (2012)

<http://cenbank.org/Out/2012/circulars/fpr/Additional\%20KYC\%20Requirement.pdf> Last accessed 11 February 2019.
} 
between Attorneys and their clients. Consequently, subjecting Nigerian Legal Practitioners under the authority and regulation of the Minister of Trade \& Investment and SCUML by virtue of sections 5 and 25 of the MLPA, CBN or any other administrative organ or agency of the Federal Government implies creating two inconsistent legal regimes to regulate the practice of law in Nigeria.

However, the NBA quest for understanding broke down when the CBN was bent on using banking regulations to force legal Practitioners to comply with the anti-money laundering regulations through her issued circular. Upon recognition by legal practitioners that they would not succumb to the regulatory authority of SCUML and directive of CBN and other federal government agencies and the consequence of their licenses being revoked or suspended, especially when they were not responsible for the issuance of the licenses; the fact that the Nigerian anti-money laundering regulation in respect to lawyers is a usurpation of the responsibility of the Legal Practitioners Disciplinary Committee, Body of Benchers and Supreme Court who are empowered to discipline legal practitioners including the revocation of their licenses, the NBA being the lawyers' body decided to institute legal proceedings against the Nigerian Federal Government and her agencies on 15 March 2013 before the Federal High Court (FHC), Abuja.

In Registered Trustees of Nigerian Bar Association v. Attorney General of the Federation \& Central Bank of Nigeria, ${ }^{32}$ the NBA did ask the court:

a) To declare section 5 MLPA null and void, in so far as they apply to legal practitioners;

b) An order that the court should delete legal practitioners from DFNIs definition as stated in section 25 MLPA;

c) An order of perpetual injunction restraining the CBN from implementing her circular with reference FPR/CIR/GEN/VOL.1/028 dated 2 August 2012 in respect to legal practitioners and (d) An order restraining the Federal Government and her agencies: SCUML, NFIU, EFCC or otherwise howsoever from seeking the implementation of the provisions of Section 5 MLPA in respect to legal practitioners ${ }^{33}$ (Lawyard, 2017; Inko-Tariah, 2016).

The presiding Judge, Justice Gabriel Kolawole, struck down sections 5 and 25 of the MLPA since they intend to impose sanctions on legal practitioners and held the sections to be in conflict with the provisions of the Legal Practitioners Act (LPA), the Rules of Professional Conduct for Legal Practitioners, and Section 192 of the Evidence Act ${ }^{34}$ (Lawyard, 2017; Inko-Tariah, 2016). The provisions already regulate the activities of legal practitioners and specifically deals with law practice. They have articulated an established modus operandi to ensure legal practitioners accountability and discipline. Contrary to the revocation/suspension of licenses and or banning of legal practitioners from the practice of law for failure to comply with section 5 MLPA, it is the Nigerian Supreme Court that keeps the roll of legal practitioners that are licensed to practice law

\footnotetext{
${ }^{32}$ Suit No. FHC/ABJ/CS/173/2013 (unreported), Certified True Copy of judgment delivered by Justice Gabriel Kolawole of the Federal High Court Abuja on 17 December 2014.

${ }^{33} \mathrm{Id}$.

${ }^{34} I d$.
} 
and the only Nigerian Judicial Institution empowered to confirm the revocation of a legal practitioner's license to practice or a lawyer's suspension haven been found wanting upon due investigations carried out by LPDC ${ }^{35}$ (Lawyard, 2017; Inko-Tariah, 2016). The court noted that there was no relationship between SCUML and legal practitioners, hence it was wrong for SCUML to be allowed to regulate and or have oversight function over legal practitioners ${ }^{36}$ (Lawyard, 2017; Inko-Tariah, 2016). Moreover, contrary to section 25 MLPA that defined DFNIs to include legal practitioners, the court noted that they ought not to have been classified as such because legal practitioners are not traders per se neither do they have customers and consequently held that legal practitioners be deleted from the said section ${ }^{37}$ (Lawyard, 2017; Inko-Tariah, 2016). In the final determination, the court perpetually restrained the CBN from implementing her circular with reference FPR/CIR/GEN/Vol.1/028 dated 2 August 2012 in respect to legal practitioners and the Federal Government and her agencies: SCUML, NFIU, EFCC or otherwise howsoever were perpetually restrained from enforcing section 5 MLPA against legal practitioners ${ }^{38}$ (Lawyard, 2017; Inko-Tariah, 2016; Onanuga, 2014).

Dissatisfied with the judgment of the FHC, the CBN instituted an appeal before the Court of Appeal (CA), Abuja. In Central Bank of Nigeria v. NBA \& Attorney General of the Federation, ${ }^{39}$ the CA affirmed the judgment of the FHC and refused to interfere with same and consequently dismissed the CBN's appeal in its entirety for lacking merit. In arriving at her decision, the CA noted that although Section 4 (1) of the Constitution of the Federal Republic of Nigeria (CFRN) 1999 (as amended) gives the National Assembly (Senate and House of Representatives) legislative powers to enact laws for the peace, order and good government of the Nigerian Federation in respect to matters under the Exclusive legislative List in Part I of the Second Schedule to the CFRN and Concurrent List in Part II of the Second Schedule to the CFRN, they have no such uninhibited legislative powers to enact laws that are beyond their legislative legal duties. ${ }^{40}$ Section 4 (8) CFRN stipulates that any law made that ultra vires their legislative powers is entitled to be struck down by the court. Prior to the enactment of the MLPA 2011 and its amendment, the National Assembly is deemed to have knowledge of the existence of the LPA, RPC and EA made by the same National Assembly, especially sections 20 and 21 which had already ensured maximum protection for legal practitioners' clients' and their monies. ${ }^{41}$ Legal Practitioners are mandated to open CLIENT'S BANK ACCOUNT where monies collected for or on behalf of a client by a legal practitioner are paid into. Legal Practitioners are seen as trustees in respect to clients' monies which should ordinarily not be mixed with monies belonging to legal practitioners in any licensed bank. ${ }^{42}$ Con-

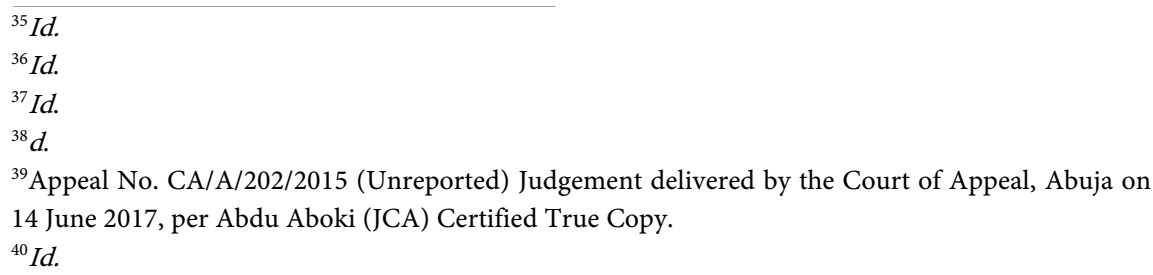


sequently, the enforcers of the MLPA can investigate such client's account directly at the bank in question. It is the bank that is responsible to carry out the identification of her customers and not legal practitioners. The LPA has already stipulated the penalty or punishment that would accrue to a legal practitioner that refuses to comply to the opening of a client's account. ${ }^{43}$ Thus, it is irresistibly obvious that the LPA and MLPA are in conflict in respect to the responsibilities of legal practitioners; their duty to clients and legal practice hence it is impossible for both laws to run side by side. ${ }^{44}$ Worse still, the National Assembly enacted the MLPA in the absence of any reference whatsoever to the LPA neither is the MLPA shown to have amended or repealed the LPA either in whole or part. ${ }^{45}$ The BLUE PENCIL rule was used to strike down sections 5 and 25 MLPA from applying to legal practitioners. ${ }^{46}$ Justice Abdu Aboki (JCA) stated thus: "I believe the learned trial judge was right in expressing preference for the provisions of the LPA over the provisions of sections 5 and 25 of the MLPA 2011 rendering the two sections of the MLPA invalid, null and void insofar as they purport to apply to legal practitioners and ... the inclusion of legal practitioners in the definition of DNFI in section 25 of the MLPA is inapplicable to legal practitioners." ${ }^{\prime 7}$ Section 5 and 25 of the MLPA 2011 was held to give way to the provisions of the LPA and the RPC made thereunder and the Evidence Act.

The CA critically examined the intention of the Anti-Money Laundering provisions of the MLPA and came to the conclusion that it is not the intention of section 5 of the MLPA to apply to legal practitioners because textually and conceptually thinking legal practitioners have no obligation to report the relationship between a legal practitioner/client to SCUML/Minister heading the Federal Ministry of Trade and Investments. ${ }^{48}$ The LPA already covers the obligation of a legal practitioner to his/her client; the manner with which he can become a legal practitioner and the role of the Supreme Court and the withdrawal of a legal practitioner's certificate or being struck off the roll of legal practitioners under the custody of the Supreme Court contrary to section 5 of the MLPA. ${ }^{49}$ The definition accorded "Transaction" in section 25 of the MLPA unequivocally shows the nature of business transaction the National Assembly intended when they enacted the MLPA. ${ }^{50}$

The transactions mentioned in section 25 of the MLPA do not form part of the business of legal practitioners. ${ }^{51}$ That being the case, at the point of making the MLPA, if the lawmakers intended legal practitioners to be inclusive, they would have made their intention obvious in the MLPA by stating in black and white, the amendment or repeal of the LPA. What the MLPA has done is to in${ }^{41} I d$.
${ }^{42} I d$.
${ }^{43} I d$
${ }^{44} I d$.
${ }^{45} I d$.
${ }^{46} I d$.
${ }^{47} I d$.
${ }^{48} I d$.
${ }^{49} I d$. 
clude legal practitioners through the "back door" i.e. the definition section as financial market(s) agents for EFCC, CBN and Ministry of Finance. ${ }^{52}$ The court stated thus: "I am of the solemn view that the arrangement made by the legislators for detecting persons engaged in Money Laundering offence via business venture or Professional advice under the Money Laundering Act is highly incongruous and in direct conflict with the LPA particularly sections $20-23$ thereof which already provided by specific provisions of the said Act the relationship between the $1^{\text {st }}$ Respondent's members and their clients ..." ${ }^{33}$

\subsection{Immunity for Nigerian Legal Practitioners or Not? Effects on the Legal Profession and Nigerian Polity}

By the CA decision, Nigerian Legal Practitioners are immune from the operation of anti-money laundering regulations with specific reference to clients/attorneys dealings. Legal practitioners do not need to register with SCUML since they are no more seen as DNFIs. These imply that any dealings between a legal practitioner and his/her client cannot be regulated by the MLPA. It must however not be mistaken that legal practitioners cannot be investigated and prosecuted for money laundering related offences and other corrupt practices by the EFCC. The $C B N$ v NBA \& Attorney General of the Federation case merely reinforces the duty of legal practitioners not to divulge privilege/confidential communication when acting on behalf of clients and consequently not obliged to report to SCUML being an unrecognized regulatory body of the legal profession. ${ }^{54}$ It has been judicially and unequivocally affirmed that matters in respect to lawyers' professional fees concerning a lawyer and his client is a privilege matter (NBA, 2018). Where a legal practitioner is questioned by the EFCC or any agent of the Nigerian Government based on legitimate proceeds accrued from clients, it constitutes an infraction of the lawyer-client privilege (NBA, 2018). The relationship between a client-lawyer is contractual in nature hence a third party like the EFCC or any other agency has no locus standi to determine the basis of lawyers professional fees except one of the parties to the contract (NBA, 2018). Questioning a lawyer's professional legal fees invariably places the EFCC or any other agency as an auditor or regulator which is absolutely absent under Nigerian Laws and an attempt to criminalize legitimate professional fees earned by legal

${ }^{50} I d$. "Transaction" means-a) acceptance of deposit and other repayable funds from the public; b) lending; c) financial leasing; d) money transmission service; e) issuing and managing means of payment (for example, credit and debit cards, cheques, travelers' cheque and bankers' drafts etc.); f) financial guarantees and commitment; g) trading for account of costumer (spot-forward, swaps, future options, etc.) in-1) money market instruments (cheques, bills CDs, etc.), 2) foreign exchange, 3) exchange interest rate and index instruments, 4) transferable securities, and 5) commodity futures trading; h) participation in capital markets activities and the provision of financial services related to such issues; i) individual and collective portfolio management; j) safekeeping and administration of cash or liquid securities on behalf of clients; k) life insurance and all other insurance related matters; and l) money changing." See MLPA 2011, s.25.

${ }^{51} I d$.

${ }^{52} I d$.

${ }^{53} \mathrm{Id}$.

${ }^{54} I d$. 
practitioners for legal services rendered (NBA, 2018). Moreover, the CA decision has reaffirmed that it is compulsory for legal practitioners to open client's bank account for purposes of depositing clients' monies. ${ }^{55}$ Being a trustee of such monies, they must ensure they are not mixed with legal practitioner's personal money. ${ }^{56}$ In this regard, the EFCC or any other agency empowered to enforce the MLPA can through the financial institutions elicit facts or intelligence, bordering on clients monies deposited in the affected accounts. ${ }^{57}$ Where a legal practitioner fails to open a client account, he would be liable to be dealt with in accordance with the LPA. ${ }^{58}$

With the pronouncement of the Nigerian CA, the FATF Recommendations in respect to lawyers ceases to have any iota of effect on legal practitioners carrying out legal practice in Nigeria, either as individuals or as law firms. The corollary is that there may be no more clients' identity checks by legal practitioners which invariably give money launderers an opportunity to target Nigerian legal practitioners and law firms for money laundering activities (Solicitors Regulation Authority, 2014). In order for money launderers to legitimize their proceeds of crime, clients account would now be an avenue for such monies to pass through and disguise same as real legal transactions, when in actual sense no legal service has been rendered (Solicitors Regulation Authority, 2014). Of course, the proliferation of sham matters which would in turn be cancelled stands to be the order of the day with the recent CA decision just to justify proceeds of crimes in clients account (Solicitors Regulation Authority, 2014). Again, clients account would now be used improperly as bank facilities with financial inducements accorded legal practitioners (Solicitors Regulation Authority, 2014). These would greatly have impact on the Nigerian government and her economy. The laundering of proceeds of crime through clients account and legal practitioners encourages the evasion of taxes by money launderers which in turn reduces resources meant for the government to engage in infrastructural development and national security (Oluwadayisi \& Mimiko, 2016).

\subsection{Comparative Overview of Nigeria's Court of Appeal Decision}

Other lawyers in other jurisdictions seem to have had same challenges faced by the NBA before the current position taken by the Nigerian CA. In Canada, the Columbian Court of Appeal and Supreme Court held that the imposed Federal Government's Regulation on the identification of client and keeping of record is a breach of the relationship between lawyer-client and consequently not germane based on the existing constitutional regulations against legal practitioners by the provincial and territorial regulators (International Bar Association, 2014). In Canada (Attorney General) v. Federation of Law Societies of Canada, ${ }^{59}$ the

${ }^{55}$ Central Bank of Nigeria v. NBA \& Attorney General of the Federation, (n. 36); Commercial Law Development Services, Exclusive Interview with Ogwemoh Sylva on Legal Practitioners and Money Laundering,(n. 21).

${ }^{56} I d$.

${ }^{57} \mathrm{Id}$.

${ }^{58} I d$. 
Canadian Supreme Court sometime in February 2015 held the non-applicability of the Anti-Money Laundering regulations of Canada to legal practitioners. From the American perspective, the application of money laundering regulations against legal practitioners in strictu sensu has been repelled by the ABA, especially in respect to reporting transactions that are suspicious and divulging client details. ${ }^{60}$ Nevertheless, some other jurisdictions like the UK Law Society have embraced FATF Recommendations in respect to legal practitioners and have consequently put in place guidelines geared towards the regulation of lawyers' activities in order to prevent them from engaging in money laundering related offences.

The next section takes a look at the UK's position with a view to articulating her approach for adaptation by the Nigerian government and NBA. It unravels that the UK has revolved the potential conflict between lawyers' duty to his or her clients' and the duty to report suspected money laundering activities in a way that has not been resolved in Nigeria.

\section{Legal Practitioners and Review of Anti-Money Laundering Regulations in Nigeria: Lessons from the United Kingdom}

The United Kingdom is a member of the European Union (EU) and consequently a beneficiary of the European Union Directives on the implementation of the FATF Recommendations in order to curtail money laundering activities and its impact on the financial driven developments (Malish, 2017a). The EU issued her first directive on money laundering in 1991 for the criminalization of money laundering and was domesticated by the UK through the Criminal Justice Act 1991, the Drug Trafficking Act 1994 and the Money Laundering Regulations 1993 (Malish, 2017b; Legal Sector Affinity Group, 2018). The second directive was issued in 2001 due to the amendments of the FATF Recommendations which included legal professionals and other service professionals to be bound by anti-money laundering regulations. This development was reflected in the UK POCA and Money Laundering Regulations 2003. Upon request for the application of due diligence through a risk-based approach; the conduct of enhanced due diligence, the EU issued the third directive in 2005, which was subsequently implemented by the UK by enacting the Money Laundering Regulations 2007, the Terrorism Act 2000 and POCA 2002 (Amendment) Regulations 2007 (the TACT and POCA Regulations 2007) (Malish, 2017b; Legal Sector Affinity Group, 2018). In a recent development, arising from changes made to the FATF Recommendations in 2012 and the aftermath of the European Commission's evaluation of the third money laundering directive on implementation, the EU issued the fourth money laundering directive which resulted to the UK's ${ }^{59}$ Lexum, Judgments of the Supreme Court of Canada, available at <https://scc-csc.lexum.com/scc-csc/scc-csc/en/item/14639/index.do > Last accessed 13 March 2019. ${ }^{60}$ H.W Goldstein, “Debate Over Lawyers' Role in Anti-Money Laundering Enforcement”, Business Crimes Bulletin <https://www.anti-moneylaundering.org/Lawyers_and_Money_Laundering.aspx $>$ Last accessed 11 February 2019; Rule 1.6: Confidentiality of Information, American Bar Association Model Rules of Professional Conduct. 
repeal and replacement of the Money Laundering Regulations 2007 with The Money Laundering, Terrorist Financing and Transfer of Funds (Information on the Payer) Regulations 2017. The 2017 Regulations highlights the required measures necessary for the regulated sector in relation to anti-money laundering control and the extent of CDD (Malish, 2017; Legal Sector Affinity Group, 2018).

Compared to other jurisdictions, the UK has developed the greatest zeal towards instituting the necessary regulatory demand in ensuring the absolute implementation of the FATF Recommendations, which has consequently made them the "gold standard" for anti-money laundering regulation in respect to legal professionals (Malish, 2017; Legal Sector Affinity Group, 2018). The UK's achievement is not farfetched when viewed against the harmonious relationship that exists between her and the Law Society in the fight against money laundering amongst legal professionals. The Law Society is a legal body that represents solicitors in England and Wales. ${ }^{61}$ The 2017 Money Laundering Regulations approved the Law Society as the supervisory regulator and believes in the UK's government ideas towards having a stronger and successful anti-money laundering regime. ${ }^{62}$ Consequently, in the detection and prevention of money laundering in the UK, Solicitors contribute and engage in very important roles. These they have successfully done through the provision of guidance in respect to members of the Law Society and establishment of cordial working relationship with the UK's government and law enforcement agents and has made several inputs on the UK legislative and policy improvement on anti-money laundering regulations. ${ }^{63}$ The SRA acts on behalf of the Law Society as the regulatory body in respect to money laundering activities by legal professionals being a beneficiary of the delegated supervisory authority of the Law Society. ${ }^{64}$ The SRA without fear or favour monitors and ensures that solicitors comply with their responsibilities pursuant to the anti-money laundering regulations. ${ }^{65}$

The absence of a harmonious and cordial relationship between the Nigerian government and her regulatory agencies on one hand and the NBA on the other hand constituted a clog to a well-established legal professional legislative and policy on money laundering regulation in Nigeria. Prior to the enactment of the anti-money laundering regulations in Nigeria, the aftermath of the development that resulted to the CA decision is a pointer to the absence of a working relationship. Although, the NBA sought to discuss and negotiate with the Nigerian government and her agencies over the administration of the anti-money laundering regulations against legal practitioners when the CBN imposed her circu-

\footnotetext{
${ }^{61}$ The Law Society, Anti-money laundering, available at

<https://www.lawsociety.org.uk/policy-campaigns/articles/anti-money-laundering-guidance/> Last accessed 11 December 2018.

${ }^{62}$ Id.; The Money Laundering, Terrorist Financing and Transfer of Funds (Information on the Payer) Regulations 2017 - 2017 Money Laundering Regulation, Regulation 7(1)(b), Schedule 1, Item 20.

${ }^{63} \mathrm{Id}$.

${ }^{64} I d$.

${ }^{65} \mathrm{Id}$.
} 
lar with reference $F P R / C I R / G E N / V o l .1 / 028$ dated 2 August 2012, both parties ended in a deadlock. A lesson that the Nigerian government and her agencies should learn from the UK's anti-money laundering regime as it relates to legal practitioners is the nod for lawyers to self-regulate and the harmonious relationship that exist between both parties. The UK's Law Society is empowered by virtue of the 2017 Money Laundering Regulations as a supervisory authority for Solicitors in England and Wales while in Nigeria, the Federal Ministry of Commerce \& Trade/SCUML is the supervisory regulatory body, a non-legal/lawyers related body under the Nigerian anti-money laundering regulation. The UK's position lays credence to the NBA's position and the subsequent CA decision in that respect. Consequently, the Nigerian anti-money laundering regulation should be reviewed to allow the NBA, similar to the Law Society to be equipped with supervisory and regulatory authority.

Another area of concern for the Nigerian government and the NBA, which requires lesson to be drawn from the UK anti-money laundering regime, is the intention of the drafters of the Nigerian anti-money laundering regulation. The intention of the UK anti-money laundering regulation clearly shows that her anti-money laundering regime is applicable to legal professionals. Regulation 8 of the UK 2017 Money Laundering Regulation expressly list "independent legal professionals" as being bound by the anti-money laundering regime and Regulation 12 went ahead to determine who an independent legal professional is and the nature of transaction or business involved ${ }^{66}$ It states that "independent legal professional" refer to "a firm or a sole practitioner who by way of business provides legal or notarial services to other persons." Legal Professionals under the employment of a public authority or working in-house are excluded. It is only when there is a risk of money laundering taking place in the activities of a legal professional that the Regulations would apply. ${ }^{67}$ Hence, it applies when a legal professional is adjudged to have participated in financial or real property transactions concerning:-

“a) buying and selling of real property or business entities; b) managing of client money, securities or other assets; c) opening or management of bank, savings or securities accounts;

d) organisation of contributions necessary for the creation, operation or management of companies; or e) creation, operation or management of trusts, companies, foundations or similar structures." ${ }^{38}$

A legal professional is seen to have participated in a transaction by assisting in the planning or execution of the transaction or otherwise acting for or on behalf of a client in the transaction. ${ }^{69}$ When juxtaposed against section 25 of the Nigerian MLPA 2011 (as amended) that defined transactions, reproduced in the previous section, it is obvious that the transactions listed does not fall within the business of a Nigerian legal practitioner. It just shows that legal practitioners ${ }^{66} 2017$ Money Laundering Regulation, Regulation 12; Legal Sector Affinity Group (2018). Anti-Money Laundering, Guidance for the Legal Sector, p.16.

${ }^{67} \mathrm{Id}$.

${ }^{68} I d$. 
were included in the definition section without resort to the nature of business they are entitled to carry out as was explicitly done under the UK's Regulation. It buttresses the earnest lack of intention of the drafters to include legal practitioners as beneficiaries of the anti-money laundering regime. Again, the Nigerian CA was right when it said that the inclusion of legal practitioners was done through the "back door." In this regard, appropriate review initiative must be taken from the UK's perspective to ensure proper allocation and inclusion of transactions Nigerian legal practitioners can engage in, for the application of the Nigerian anti-money laundering regulation.

In addition, the Nigerian anti-money laundering regime creates a conflicting scenario where lawyer-client relationship is jeopardized, thereby exposing the Nigerian lawyer to provisions of the Money laundering regulation in contradiction to the LPA, RPC, EA. From the UK's perspective, despite the robust money laundering provisions, there seem not to be any iota of relegation of the lawyer-client relationship, neither is there a conflict amongst the anti-money laundering obligations in respect to lawyers. Regulations 27, 28 and 30 of the 2017 Money Laundering Regulations requires legal professionals to undertake a risk based approach and conduct a customer due diligence sequel to establishing any business relationship; transactions amounting to 15,000 Euros or more; suspicious money laundering or terrorist financing activities; determination of the authenticity or otherwise of documents or information obtained previously for purposes of identification and verification. ${ }^{70}$ Similar provisions are provided in section 3 of the Nigerian MLPAA 2012. The beauty of the UK's position which the Nigerian government need to take cognizance of is Regulation 31(3) of the 2017 Money Laundering Regulations ... "does not apply where an independent legal professional or other professional adviser is in the course of ascertaining the legal position for a client or performing the task of defending or representing that client in, or concerning, legal proceedings, including giving advice on the institution or avoidance of proceedings." ${ }^{\text {71 }}$

Notably, section 327 POCA prohibits a legal professional from concealing, disguising, converting, transferring or removing criminal property from England and Wales, Scotland or Northern Island, penalty on summary conviction is up to six months' imprisonment or a fine or both; section 329 punishes legal professionals that acquires, uses or possesses criminal property for up to 14 years' imprisonment or a fine or both; and while section 330 punishes a legal professional upon summary conviction up to six months' imprisonment or a fine or both for failing to disclose knowledge, suspicion or reasonable grounds of money laundering. These provisions are in pari materia to the amended section 15 of the Nigerian MLPA 2011 reproduced in the previous section of this work. Again, under sections 330 (6) (b), (10) and (11) POCA, recognition is given to privilege communication between legal professionals and their clients under the

${ }^{70} 2017$ Money Laundering Regulations, Regulation 27, 28 \& 30.

${ }^{71}$ Note Regulation 33 that talks about the application of Enhanced Due Diligence. 
UK anti-money laundering regime. ${ }^{72}$ For instance, section 330 (6) (b) POCA states that "But a person does not commit an offence under this section if he is a professional legal adviser and the information or other matter came to him in a privileged circumstances." The only provisions that accords legal professionals privilege communication are the LPA, RPC and EA which have been declared to be in conflict with the Nigerian anti-money laundering regulation and consequently inoperative against legal practitioners in Nigeria. What the Nigerian government should do in the circumstance to stem the tide of prevention of laundering of proceeds of crime and curb the challenges being faced in the implementation of anti-money laundering in respect to legal practitioners, is to adopt and reflect the UK's anti-money laundering regime with particular reference to legal practitioners through an overhaul and amendment of the current Nigerian anti-money laundering regulations.

The corollary is that the Nigerian anti-money laundering regulations offend the FATF Recommendation that gives priority to legal professionals and clients privilege communication. The Interpretative Note to FATF Recommendation 23 (DNFBPS: Other Measures) provides that lawyers or legal professionals "are not required to report suspicious transactions if the relevant information was obtained in circumstances where they are subject to professional secrecy or legal professional privilege." ${ }^{\prime 3}$ The professional secrecy or legal professional privilege could be at the point of ascertainment of clients' legal position or in course of carrying out legal services of defense or representation of a client or in respect to judicial, administrative, arbitration or mediation proceedings. ${ }^{74}$ Lawyers are even permitted to self-regulate. "... may allow lawyers to send their STR to their appropriate self-regulatory organizations." 75 The UK's compliance of the FATF Recommendations is further exhibited in the case of Three Rivers District Council and others $v$ the Bank of England ${ }^{6}$ where the court stated that advise privilege covers every communication between a lawyer and his client in respect to dealings where the lawyer has been instructed with derivable legal advice, irrespective of absence of advice specifically on issues of law and construction, provided that the advice impinge on or is part of or linked to the lawyers professional duty as the clients legal adviser.

In another development, the impact of the SRA towards the successes built thus far in the implementation of the UK's anti-money laundering regime in respect to legal professionals cannot be overemphasized. The SRA believes in lawyers significant obligation towards the fight against money laundering in the UK. For instance, under outcome 7.5 of the SRA Code of Conduct, UK Solicitors




are obliged to "comply with ... anti-money laundering ... legislation." Several guidelines have also been produced for the assistance of independent legal professionals in order to meet up their responsibilities provided under the UK anti-money laundering regime (Malish, 2017a). The NBA must think towards this direction. The bus should not stop at the victory against the Nigerian government in the case of $C B N V_{V} N B A$ \& Attorney General of the Federation. The LPA and RPC should be reviewed to reflect legal practitioners to comply with anti-money laundering legislation taking a clue from the UK SRA. Moreover, considering the important and unwavering role of lawyers in the administration of justice and making persons lawfully comply with regulations involving financial and commercial matters, the NBA should put in place an "NBA Anti-Money Laundering and Anti-Terrorism Financing Guidelines" for the observance of lawyers generally and law firms just like the Law Society and SRA have done in the UK.

Summary of lessons for Nigeria based on the UK anti-money laundering regime are as follows: The Nigerian government must develop the political will to ensure the total implementation of the FATF Recommendations as shown to have been done by the UK government. The UK has developed the greatest zeal towards instituting the necessary regulatory demand in ensuring the absolute implementation of the FATF Recommendations, which has consequently made them the "gold standard" for anti-money laundering regulation in respect to legal professionals. This is as a result of the harmonious relationship that exists between her and the Law Society in the fight against money laundering amongst legal professionals. The absence of a harmonious and cordial relationship between the Nigerian government and her regulatory agencies on one hand and the NBA on the other hand constituted a clog to a well-established legal professional legislative and policy on money laundering regulation in Nigeria The $\mathrm{Ni}$ gerian anti-money laundering regulation does not clearly show that her anti-money laundering regime is applicable to legal professionals compared to the UK anti-money laundering regime. The Nigerian anti-money laundering regime creates a conflicting scenario where lawyer-client relationship is jeopardized, thereby exposing the Nigerian lawyer to provisions of the Money laundering regulation in contradiction to the LPA, RPC, EA. From the UK's perspective, despite the robust money laundering provisions, there seem not to be any iota of relegation of the lawyer-client relationship, neither is there a conflict amongst the anti-money laundering obligations in respect to lawyers. With the pronouncement of the Nigerian CA, the FATF Recommendations in respect to lawyers ceases to have any iota of effect on legal practitioners carrying out legal practice in Nigeria, either as individuals or as law firms. The implication is that the Nigerian anti-money laundering regulations offend the FATF Recommendation that gives priority to legal professionals and clients privilege communication. The Nigerian Government and the NBA must work together to amend the offending provisions of the Money laundering regulation. The Nigerian LPA and RPC should be reviewed to reflect legal practitioners to comply with anti-money 
laundering legislation, taking a clue from the UK SRA. The NBA should put in place an "NBA Anti-Money Laundering and Anti-Terrorism Financing Guidelines" for the observance of lawyers generally and law firms just like the Law Society and SRA have done in the UK

\section{Conclusion}

The peculiarity of the global nature of legal services rendered to clients by legal professionals underscores the basis for the imposition of anti-money laundering obligations on legal professionals. A lack of regulation for money laundering is capable of threatening the global community, which may result in revenue loss; endangering of lives and encouraging the proliferation of heinous criminal activities. In this regard, FATF decided to put in place global policies in the form of FATF Recommendations and extended it to legal professionals. Countries are expected to enact money laundering legislation to reflect these policies at the domestic level and extend the same to legal professionals. Unfortunately, most countries have experienced challenges, arguably arising from curtailment on existing relationship between legal professionals and their clients concerning privilege communication and its impact on reporting obligations with respect to money laundering. This development is the result of the Nigerian government's enactment of the MLPA 2011 (as amended) and the subsequent agitation by $\mathrm{Ni}$ gerian lawyers (NBA) for the regulation to be struck down against legal professionals when the Nigerian government and her agencies sought to implement the regulation against legal professionals. In a considered judgment by the Nigerian CA in $C B N_{V} N B A$ \& Attorney General of the Federation, ${ }^{77}$ the Nigerian anti-money laundering regulations were held not to be binding on legal professionals and the Nigerian government and her agencies were perpetually restrained from enforcing same against legal professionals on the premise of conflict with existing laws (LPA, RPC \& EA) regulating legal professionals and impliedly, its infringement on lawyer-client privilege principle relationship. The corollary is that legal professionals in Nigeria have been excluded from being regarded as DFNIs or DNFBPs, hence dealings between legal professionals and clients ceases to be confined under the ambit of the MLPA 2011 (as amended). Obviously, this contradicts the FATF Recommendations in respect to legal professionals. This paper has highlighted the challenges Nigeria's present position may pose in the global fight against money laundering. Comparatively, while suggestions have been given towards a review of the Nigerian anti-money laundering regulations, the UK's anti-money laundering regime with respect to legal professionals is recommended for adaptation by the Nigerian government and NBA for an effective and efficient fight against money laundering in Nigeria.

\section{Conflicts of Interest}

The authors declare no conflicts of interest regarding the publication of this

${ }^{77}$ Appeal No. CA/A/202/2015 (Unreported) Judgement delivered by the Court of Appeal, Abuja on 14 June 2017, per Abdu Aboki (JCA). 
paper.

\section{References}

De Koker, L. (2007). South African Money Laundering and Terrorism Financing Law (p. 4). Durban: LexisNexis.

Eze, C. (2013). Challenges of Implementing Money Laundering against Lawyers. http://thenationonlineng.net/challenges-of-implementing-money-laundering-against-l awyers-4

FATF (2012). International Standards on Combating Money Laundering and the Financing of Terrorism \& Proliferation. FATF Recommendations, the Interpretative Note to FATF Recommendation 23, Paris: FATF.

http://www.fatf-gafi.org/recommendations.html

FATF-GAFI (2008). Financial Action Task Force, RBA Guidance for Legal Professionals.

Gaetke, E. R., \& Welling, S. N. (1992). Money Laundering and Lawyers. Syracuse Law Review, 43, 1165-1245.

History of Anti-Money Laundering Laws. U.S. Dept. of the Treasury, Fin. Crimes Enforcement Network. https://www.fincen.gov/history-anti-money-laundering-laws

Inko-Tariah, N. A. T. (2016). Applicability of Anti-Money Laundering Laws to Legal Practitioners in Nigeria: NBA v. FGN \& CBN. Journal of Money Laundering Control, 19, 329-336. https://doi.org/10.1108/JMLC-09-2015-0038

International Bar Association, the American Bar Association and the Council of Bars and Law Societies of Europe (2014). A Lawyer's Guide to Detecting \& Preventing Money Laundering (p. 10).

http://www.ccbe.eu/fileadmin/user upload/NTCdocument/01748 MKT SGP Lawyer 1 1413961642.pdf

Lawyard (2017). Court Nullifies Section 5 of Money Laundering Act. https://www.lawyard.ng/court-nullifies-section-5-of-money-laundering-act

Legal Sector Affinity Group (2018). Anti-Money Laundering, Guidance for the Legal Sector (pp. 12-16).

Malish, R. (2017a). Can US Lawyers Be Trusted to Regulate Themselves? https://www.niceactimize.com/blog/Regulation-of-UK-lawyers-as-gatekeepers-for-AM $\underline{\mathrm{L}-538}$

Malish, R. (2017b). Regulation of UK Lawyers as Gatekeepers for AML-The UK as a Leader in Anti-Money Laundering Regulations.

https://www.niceactimize.com/blog/Regulation-of-UK-lawyers-as-gatekeepers-for-AM $\underline{\mathrm{L}-538}$

NBA (2018). Address by the President of the NBA Delivered at the NBA National Executive Committee ("NEC") Meeting Held at the NBA Secretariat in Abuja.

https://Www.Nigerianbar.Org.Ng/Index.Php/News1/900-Nec

Ogundipe, B. (2015). Domestic \& International Anti-Money Laundering Regime: Measures in Place in Nigeria, Being a Speech Delivered at the NBA Anti-Corruption Conference Held on 24 June 2015 (Nigera, Thisday, 30 June 2015).

https://www.pressreader.com/nigeria/thisday/20150630/281943131537747

Oluwadayisi, A. O., \& Mimiko, M. O. (2016). Effects of Money Laundering on the Economy of Nigeria. Beijing Law Review, 7, 158-169.

https://doi.org/10.4236/blr.2016.72017

Onanuga, A. (2014). Court Restraints Fed Govt, CBN SCUML from Enforcing Money 


\section{Laundering Act on Legal Practitioners.}

http://thenationonlineng.net/court-restraints-fed-govt-cbn-scuml-enforcing-money-la undering-act-legal-practitioners

Reider-Gardon, M. et al. (2012). International Anti-Money-Laundering. International Lawyer, 46, 375-388.

Rose, N. (2009). Making the Case for Appropriate Anti-Money Laundering Rules for Lawyers (pp. 37-39). IBA News.

http://www.anti-moneylaundering.org/AMLResources.aspx

Schlenter, B. (2013). The Taxing Business of Money Laundering: South Africa. Journal of Money Laundering Control, 16, 128. https://doi.org/10.1108/13685201311318485

Solicitors Regulation Authority (2014). Cleaning Up Law Firms and the Risk of Money Laundering.

http://www.sra.org.uk/documents/solicitors/freedom-in-practice/money-laundering.pd $\underline{f}$

Terry, L. S. (2014). U.S. Legal Profession Efforts to Combat Money Laundering and Terrorist Financing. New York Law School Law Review, 59, 487-518.

Yantis, B. et al. (2018). Money Laundering. American Criminal Law Review, 55, 1469. 